\title{
Qualified laws as actors of the separation of powers
}

\author{
BOLDIZSÁR SZENTGÁLI-TÓTH ${ }^{1,2 *}$
}

${ }^{1}$ Centre for Social Sciences, Institute for Legal Studies
${ }^{2}$ Constitutional Law Department of the Eötvös Loránd University

ORIGINAL RESEARCH PAPER

Received: January 31, 2020 • Revised manuscript received: August 16, 2020 • Accepted: February 20, 2021

(C) 2021 The Author(s)

\begin{abstract}
Over the last few decades, several countries have entrenched a special subcategory of law, which is adopted by stricter procedural rules than the requirements of the ordinary legislative process. These laws are enacted by qualified majority, by the consent of the two chambers of the legislation, and are subject to mandatory constitutional review before their promulgation, or additional safeguards are implemented in the ordinary legislative process. It is beyond doubt that this legal instrument influences the prevalence of the separation of powers and the constitutional principle of democracy in a remarkable way; therefore, it might be an important tool for populist politicians to concrete their preferences for the long term. In this study, my aim is to conceptualize the most highly contested issues regarding the legal nature of qualified laws, and to provide a deeper understanding of the interdependence between qualified laws and the separation of powers. This analysis might also clarify how qualified laws may serve the ambitions of populist political groups in certain specific circumstances. My contribution provides general theoretic considerations, and does not outline the particular constitutional frameworks in detail. I would rather just use the specific examples to demonstrate how the mechanism of qualified law works in practice as an instrument of constitutional law.
\end{abstract}

\section{KEYWORDS}

qualified law, democracy, separation of powers, parliamentarism, legislation, hierarchy of norms

\footnotetext{
* Corresponding author. E-mail: szentgali-toth.boldizsar@tk.hu

This study forms part of a research project (Code: NKFIH128796) funded by the Hungarian Office of Research, Development and Innovation, which outlines the current normative content of the principle of democracy from the perspective of European Union- and constitutional law.
} 


\section{THE TERM 'QUALIFIED LAW'}

As a preliminary consideration, the term 'qualified law' will be defined. The relevant national legal systems outline the concept of qualified law in different ways; however, certain common points are identifiable among the various approaches. Qualified law is a constitutionally prescribed subcategory of laws which covers - at least in theory - the most crucial legislative fields, and which is subject to stricter procedural safeguards than the requirements of the ordinary legislative process. ${ }^{1}$

The different national legal systems apply a wide range of expressions to define qualified laws. Although the fact that the terminology used is not a decisive factor for a substantial analysis, in this particular case, it is worth assessing this issue, since the terminology clearly demonstrates the different functions of this legal concept: the constitutional, the political, the historical and the sovereignty-based approach will be highlighted.

The term organic law is used by the Constitutions of France, ${ }^{2}$ Spain, ${ }^{3}$ Romania and Moldova. This terminology focuses on the approach adopted by constitutional law. In Spain, organic laws fall within the broader constitutional design, the constitutional bloc, and in most relevant constitutional systems, organic laws may be invoked during the constitutional review of ordinary laws. ${ }^{4}$

The category of 'laws with constitutional force' was introduced in Hungary during the democratic transition; these laws had the same legal force as the articles of the Constitution. ${ }^{5}$ The form 'laws adopted by a two-thirds majority' was also applied in Hungary over the two decades between 1990 and 2011. This approach highlighted the political relevance of the concept: instead of simple majority, broad consent was necessary to adopt or amend qualified laws.

The Fundamental Law of Hungary established, or even reinstated, a new legal concept, the cardinal law, ${ }^{6}$ which had almost the same logic as the former 'laws adopted by a two-thirds majority'. This symbolic step strengthened the historical rhetoric of the new Fundamental Law. ${ }^{7}$

France, Spain and Hungary represent three main models for legislation with a qualified majority. However, the issue of qualified law concerns not only these three countries, but also several other constitutional systems around the world. In spite of the fact that some elements of the English constitutional development were close to the logic of qualified law, ${ }^{8}$ the modern history of qualified law dates back to 1958, when the Constitution of the Fifth French Republic was adopted. ${ }^{9}$ Since the decolonization of Africa, numerous African countries have implemented

\footnotetext{
${ }^{1}$ Camby (1998) 1686-98; Jakab (2014) 96-110; Avril and Gicquel (2014) 267-307.

${ }^{2}$ Art. 46. of the Constitution of France [04.10.1958].

${ }^{3}$ Art. 81. (1) of the Constitution of Spain [07.12.1978].

${ }^{4} \mathrm{~N}^{\circ}$ 66-28, DC du 8 juillet 1966 (Rec., p. 15).; Troper (2012) 346.

${ }^{5}$ Kilényi (1994b) 201-209.

${ }^{6}$ Art. T. (4) of the Fundamental Law of Hungary [25.04.2011].

${ }^{7}$ Küpper (2014) 2-5.

${ }^{8}$ Leyland (2012) 25-42.

${ }^{9}$ Art. 46. of the Constitution of France [04.10.1958].
} 
organic law in their constitutional design; ${ }^{10}$ currently, approximately 21 African Constitutions provide expressly organic law, including Algeria, ${ }^{11}$ Senegal, ${ }^{12}$ and Tunisia, ${ }^{13}$ and other countries across the continent. ${ }^{14}$

The second wave of the spread of qualified law was attached to the fall of nationalist dictatorships in Spain and Portugal: ${ }^{15}$ qualified laws were introduced in both constitutions, ${ }^{16}$ and later, this sample was followed by a considerable number of Latin-American countries, such as Ecuador, ${ }^{17}$ or Venezuela, ${ }^{18}$ while other countries are also relevant. ${ }^{19}$ Finally, the third wave of the spread of qualified law occurred after the failure of the communist regimes, with this solution being implemented in the Hungarian, in the Romanian, ${ }^{20}$ and in the Moldovan ${ }^{21}$ constitutional systems, as well.

Apart from this, after the democratic transition some former soviet republics also implemented organic laws, but the relevant constitutional articles were later repealed. ${ }^{22}$

\section{THE THEORETICAL BACKGROUND OF THE SEPARATION OF POWERS}

The theoretical and practical concept of separation of powers is a key element of the modern interpretation of the state and constitutionality, and without this framework the development of the political structure and theory of the state could not be understood properly.

\footnotetext{
${ }^{10}$ David (1964) 630.

${ }^{11}$ Art. 123. of the Constitution of Algeria [15.05.1996].

${ }^{12}$ Art. 78. of the Constitution of Senegal [07.01.2001].

${ }^{13}$ Art. 65. of the Constitution of Tunisia [26.01.2014].

${ }^{14}$ Art. 166. (2) b) and Art. 169. (2) of the Constitution of Angola [21.01.2010]; Art. 97. of the Constitution of Benin [02. 12.1990]; Art. 155. of the Constitution of Burkina Faso [02.06.1991]; Art. 127. of the Constitution of Chad [1996]; Art. 66. of the Constitution of Djibouti [1992]; Art. 104. of the Constitution of Equatorial Guinea [1991]; Art. 71. of the Constitution of Ivory Coast [08.11.2016]; Art. 60. of the Constitution of Gabon [1991]; Art. 83. of the Constitution of Guinea [07.05.2010]; Art. 124. of the Constitution of the Democratic Republic of Congo [18.02.2006]; Art. 125. of the Constitution of the Republic of Congo [2001]; Art. 52. 70. 73. 77. 80. 85. 87. 89. 92. 93. 99. 101. 102. 103. and 105. of the Central African Republic [27.12.2004]; Art. 88. and 89. of the Constitution of Madagascar [14.11.2010]; Art. 85. and 86. of the Constitution of Morocco [01.07.2011]; Art. 67. of the Constitution of Mauritania [12.07.1991]; Art.131. of the Constitution of Niger [31.10.2010]; Art. 92. of the Constitution of Togo [14.10.1992]; Art. 73. (3) and Art. 86. (2) b) of the Constitution of Cape Verde Islands [1980].

${ }^{15}$ Art. 81. (1) of the Constitution of Spain [07.12.1978]; Art. 136. (3) of the Constitution of Portugal [02.04.1976].

${ }^{16}$ Conversi (2002) 223-44.

${ }^{17}$ Art. 133. of the Constitution of Ecuador [28.09.2008].

${ }^{18}$ Art. 203. of the Constitution of Venezuela [20.12.1999].

${ }^{19}$ Art. 63. of the Constitution of Chile [21.10.1980]; Art. 112. of the Constitution of the Dominican Republic [13.06.2015]; Art. 151. of the Constitution of Colombia [04.07.1991]; Art. 164. of the Constitution of Panama [1972]; Art. 106. of the Constitution of Peru [31.12.1993].

${ }^{20}$ Art. 73. (3) of the Constitution of Romania [08.12.1991].

${ }^{21}$ The Constitution of Moldova, Art. 61. (2), Art. 63. (1) and (3), Art. 70. (2), Art. 72.((3) and (4), Art. 74. (1), Art. 78. (2), Art. 80. (3), Art. 97, Art. 99. (2), Art. 108. (2), Art. 111. (1) and (2), Art. 115. (4), Art. 133. (5) [29.07.1994].

${ }^{22}$ Except for Georgia, where organic law still exists: Art. 66. (2) of the Constitution of Georgia [24.08.1995].
} 
Before the Enlightenment, the uniformity and the divine origin of state authority were the generally held theories, ${ }^{23}$ although certain elements of the separation of powers were also present in the philosophy of Plato (the division of society among philosophers, soldiers and workers). ${ }^{24}$

In the ancient democratic city states, in the Roman Republic, and later in the feudal states, the executive power was not considered as unlimited, but the framework of checks and balances was not elaborated in its entirety. ${ }^{25}$ At the end of the Middle Ages and at the beginning of the modern era, the privileged social groups often came into conflict with the ruler in various countries, such as England and Hungary; the nobility were vested with bylaws which gave them the right to resist legally ${ }^{26}$ It was the exclusive rights of the feudal diet to vote on taxes, and on the recruitment of soldiers, and this constituted an effective instrument for the privileged social orders to influence the decisions of the king. ${ }^{27}$

The limitation of the royal competences was strengthened during the $18^{\text {th }}$ century with the spread of enlightened views, and made a significant impact on the constitutional design of each country. ${ }^{28}$ In this period, the theory of transcendent state authority was no longer relevant; philosophers took into account more rational considerations to establish a new political structure which would better serve the interests of each citizen. This demand initially emerged in France with Montesquieu, ${ }^{29}$ and was followed shortly afterwards in North-America. The NorthAmerican version was the multipolar interpretation of state power, where the different constitutional actors check and limit each other mutually, so none of them can obtain an overly strong grip on power. ${ }^{30}$

The concept of the separation of powers has covered two inherently different approaches from the very beginning: the theory of the separation of powers, and the priority of checks and balances. Owing to recent academic developments, the current theory of the separation of powers is now more complex than its earlier version, and distinguishes among more than three branches of power $^{31}$ (for instance, the constitutional court, civil society, or the media).

The original approach of the separation of powers was elaborated in France by Montesquieu, and further developed by the founding fathers of the United States of America, who were the first to put it into practice. ${ }^{32}$ Later, two main approaches of this theory were conceptualized. According to one interpretation, the primary question is the strict separation of the three main branches of power: the legislative, the executive, and the judicial branches. These three branches are independent of each other as regards their organisation, staff and activities. The main

\footnotetext{
${ }^{23}$ Kilényi (1994a) 268-78.

${ }^{24}$ Plato (1996).

${ }^{25}$ Montesquieu (1964) 177-78.

${ }^{26}$ Molnár (2001) 32-33.

${ }^{27}$ Hajdú (1997).

${ }^{28}$ Troper (1992) 1-15.

${ }^{29}$ Montesquieu (1949).

${ }^{30}$ Federalist (1788).

${ }^{31}$ Bibó (1986) 393-94.

${ }^{32}$ Laski (1919) 74.
} 
purpose of safeguarding the separation of powers is to secure and strengthen this clear distinction. It should be noted, again, that this approach with its three branches is still cited frequently, but the current literature relies on more independent constitutional actors, including the head of state, the constitutional court, or the media. The weakness of this approach is the neglect of the interdependence between the branches of power, and it describes the constitutional framework as the composition of various collateral, but fully independent entities. ${ }^{33}$ Furthermore, this approach cannot classify those cases in which one individual is present in more than one branch of power (for instance, when the deputies are also members of the government).

In my view, the concept of checks and balances can offer a more realistic assessment of the constitutional system. According to this theory, the branches of power are not absolutely independent from each other during the fulfilment of their constitutional tasks; they are forced to cooperate with each other. The main purpose is to prevent the development of an overly strong position of any constitutional actor vis a vis the others; the constitutional framework safeguards the interdependence of the branches of constitutional power. Each constitutional actor has an impact on the staff of other branches, on the establishment of the legal environment, and on the internal structure of each constitutional actor. Those constitutional provisions are substantial elements of the separation of powers which strengthen the balance between the different branches of power. ${ }^{34}$ Therefore, this approach highlights the balanced relationship between constitutional actors, rather than their full independence. The effective functioning of the state can be demonstrated by the room for manoeuvre of the constitutional actors, and this system of relations is grounded on reciprocity. This interpretation does not provide an exclusive list of branches of power; it operates on the principle of balance, which should be introduced into the whole constitutional framework. ${ }^{35}$

\section{THE DISTINCTION BETWEEN A TWO-THIRDS MAJORITY AND AN ABSOLUTE MAJORITY}

Qualified laws have two main models: cases in which these statutes should be adopted by a twothirds majority of the deputies, and cases in which an absolute majority of all parliamentarians is sufficient instead of the majority of the representatives who are present at the particular vote. The requirement of a two-thirds majority influences the relationship between constitutional actors in at least three respects. Firstly, the distinction between a two-thirds and a simple majority provides a new ground for the constitutional court to exercise control of constitutionality: qualified laws adopted without a two-thirds majority should be annulled by the constitutional court. ${ }^{36}$ This dimension of the separation of powers should be highlighted, i.e. situations in which qualified laws are subject to a mandatory a priori constitutional review. It should be noted that even such a system would not prevent the neglect of the two-thirds

\footnotetext{
${ }^{33}$ Sári (2000) 25-26.

${ }^{34}$ Cservák (2002).

${ }^{35}$ Kukorelli (1995) 71.

${ }^{36} 4 / 1993$. (II. 12.) ruling of the Constitutional Court of Hungary, ABH 1993, 48.
} 
requirement, since laws adopted by the parliament with a simple majority would not have been sent to the constitutional court, so this duty would only apply to those laws which are classified by the legislator itself as qualified acts.

Legislation with a two-thirds majority concerns the relationship between the government and the parliament: the governmental majority is not sufficient for the enactment of a bill; therefore, the parliament imposes substantial limits on the governmental room for manoeuvre. This may also occur in the case of legislation with a simple parliamentary majority; however, this is deemed to be an extraordinary case, due to the parliamentary support for the government. ${ }^{37}$

In the case of a two-thirds parliamentary majority behind the government, the government can realise its intention unilaterally, and is able to prevent future governments from amending the adopted acts. This phenomenon is often considered the temporal aspect of the separation of powers: the room for manoeuvre of future governments is significantly narrowed by current decisions. $^{38}$

These tendencies are less relevant under a regime of an absolute majority. The less powerful requirement of a qualified majority often correlates with a governmental majority, therefore, it does not modify significantly the relationship between the government and the parliament, i.e. between the government and the parliamentary opposition. ${ }^{39}$ The current government is not able to influence the decisions of future governments, as the participation of the opposition is necessary to amend qualified acts. The status of the constitutional court is also less concerned in cases involving an absolute majority; nevertheless, operating with two types of legislative majority extends the scope of constitutional control.

\section{THE ROLE OF QUALIFIED LAWS IN THE RELATIONSHIP BETWEEN THE GOVERNMENT AND THE PARLIAMENT}

Below, I will assess the three main points of contact between qualified laws and the separation of powers. Firstly, I focus on the relationship between the government and the parliament. An important function of the parliament is to exercise continuous control over the government via several instruments, including the question, the interpellation, and parliamentary reports. ${ }^{40}$ These instruments are not so efficient when they are used by pro-governmental deputies, who probably do not criticise policies of the government. ${ }^{41}$ As a consequence, the real parliamentary check on the executive is expected from the opposition, who concentrate on the short-comings and mistakes occurring during the work of the government. A qualified majority always highlights the role of the parliamentary opposition, so the relationship between the government and the parliament, and consequently between the government and the parliamentary opposition, changes to a remarkable degree. The forms of parliamentarism can be strengthened, and the government should take parliament into account as a substantive limit: without a qualified

\footnotetext{
${ }^{37}$ Kilényi (1994b) 201-209.

${ }^{38}$ Möllers (2013) 80.

${ }^{39}$ Kilényi (1994b) 201-209.

${ }^{40}$ Küpper (2009) 1376-87.

${ }^{41} 3 / 1991$. (II. 7.) ruling of the Constitutional Court of Hungary, ABH 1991, 15-17.
} 
governmental majority, the opposition could influence the work of the government efficiently, and it could even block the whole legislative process. With the help of the control instruments, the government needs to confront its own its mistakes, while as a result of parliamentarism, the real or alleged issues are shared with the broader political community. Within the framework of traditional parliamentarism, the parliament only corrects the decisions of the government in some respects; however, the system is based on strong cooperation between the government and the parliament. In France, in a semi-presidential system, cohabitation ${ }^{42}$ clearly demonstrates how important the support of the parliamentary majority is for the government. The government focuses on the political and constitutional conflicts with the parliament instead of implementing its long-term policies. The other side of this coin is that when the legislation at issue does not support the politics of the government, the governmental bills might be amended in significant ways during the public parliamentary debates and closed-door negotiations. This tendency is worth contemplating, since it transfers the substantial debates from the parliamentary sittings to the informal meetings of the parties. This can result in compromises based on current political interests, which leads to the neglect of the relevant professional aspects of the issues involved. ${ }^{43}$

According to the traditional interpretation of the separation of powers, the task of the government is to implement its long-term policies during its term of office, while the opposition intends to amend the decisions of the government, and also aims to convince the voters to dismiss the government at the next parliamentary elections. The role of the government and the opposition is obviously not linked to particular political parties: the current opposition could win the next election, and gain power. In certain respects, qualified laws reconsider this model: the opposition might play a crucial role during qualified legislation, since without its consent, qualified statutory norms might not be amended. This concept can be interpreted in two different ways. On the one hand, qualified laws may be seen as safeguards, since the current parliamentary majority is not able to amend the most important statutory norms. On the other hand, qualified legislation would render the governance of the country impossible by granting quasi legislative power to the opposition.

From the perspective of the separation of powers, a qualified majority limits the government's room for manoeuvre. The government is vested with broad competences to realise its policies, and to change the legal environment during its mandate. The rule of law requires a constitutional limitation of these competences. The Hungarian model of qualified legislation should be understood within this context: the government does not have unrestricted room for manoeuvre; certain constitutional actors should exercise a check on the executive power.

However, it is questionable whether the theory of the separation of powers could justify the exceptional treatment of the most important acts. The arguments for this approach tacitly presuppose an extension of the constitution: the most important fields of legislation detail the execution of certain crucial constitutional provisions, so broad consent is required; consequently, a widely based social consensus supporting these decisions is constitutionally reasonable. The main counterargument is the restriction of governmental authorisation with the

\footnotetext{
${ }^{42}$ Cohabitation means that the president of the republic and the parliamentary majority come from different political parties; therefore, these two actors have different political preferences.

${ }^{43}$ Petrétei (2003) 329-58.
} 
special protection of the most important laws. ${ }^{44}$ One can argue that this is not a black and white issue, but it is clear that as regards the first aspect of the separation of powers examined here, a qualified majority weakens the position of the government, and strengthens the weight of the parliament. Nevertheless, it should be also taken into consideration that in the case of a twothirds parliamentary majority behind the government, these tendencies can be reversed.

A qualified majority significantly restructures the political mechanisms linked to the legislation, and I have briefly analysed these phenomena in the previous section. Here, it is sufficient to repeat that the government is forced to negotiate continuously with other political parties in order to amend qualified laws. This is an appropriate point to demonstrate that qualified laws concern the relationship between the government and the parliamentary opposition, and not primarily between the government and the whole parliament. This is the characteristic which distinguishes the current cardinal laws from laws in the same category in the historic constitution of Hungary. ${ }^{45}$ While during the early modern period, cardinal laws covered the relationship between the king and the privileged social orders, cardinal laws currently constitute an instrument allowing a reconsideration of the status of the government and the parliamentary opposition. Therefore, from the perspective of the separation of powers, it is clearly demonstrable that despite certain similarities, the current notion of cardinal law is not the equivalent of the same term used in the historic constitution. ${ }^{46}$

\section{THE ROLE OF QUALIFIED LAWS IN THE RELATIONSHIP BETWEEN THE GOVERNMENT AND THE CONSTITUTIONAL COURT}

Qualified laws always extend the competences of the constitutional court vis-a-vis the government. It is also noteworthy that the main considerations of this section are also relevant for the link between the parliament and the constitutional court. During a constitutional review, in addition to other constitutional aspects, the constitutional court also takes into account whether the particular act has been adopted with a sufficient majority. The Hungarian, and also other constitutional courts, have provided that a qualified majority is not only a formal, but also a substantial constitutional requirement, ${ }^{47}$ but none of the constitutional courts have annulled any law on the sole ground that it was adopted exclusively with the votes of the pro-governmental parliamentarians. Therefore, a qualified majority is mostly a numerical, and not a substantive requirement, and there is only a political, but no constitutional expectation to negotiate with the opposition. ${ }^{48}$ Bearing this in mind, the weight of the constitutional court increases, but its political character is also strengthened, since most rulings on qualified laws are politically very sensitive. Constitutional review has a paramount importance as regards qualified laws since it is

\footnotetext{
${ }^{44}$ Sári (2000) 25-26.

${ }^{45}$ Küpper (2004) 265-74.

${ }^{46}$ Küpper (2014) 4.

${ }^{47} 4 / 1993$. (II. 12.) ruling of the Constitutional Court of Hungary, ABH 1993, 48.; JCC no. 236-2007.; $\mathrm{n}^{\circ} 84-177$ DC du 30 aout 1984.

${ }^{48}$ The oral interview with Somogyvári István [27.10.2016].
} 
more difficult to amend these laws than ordinary laws. In conclusion, the constitutional court plays a crucial role in filtering out unconstitutional amendments to qualified laws.

There are other important matters before constitutional courts which might also be relevant for the analysis of qualified laws. It is always doubtful which fields of legislation should be covered by the qualified majority requirement, and to what extent, even if qualified provisions are provided explicitly by specific statutory clauses, as they currently are in Hungary. ${ }^{49}$ In the case of clauses it is also questionable whether these provisions are in compliance with the constitutional requirements, i.e. whether the legislature has overstepped its constitutional competence. $^{50}$

As the main body for the protection of the constitution, the constitutional court has the primary responsibility to reflect on these issues, and the approach of the constitutional court is binding for each stakeholder. In my view, in the long term, a separate test should be elaborated to outline the scope of qualified legislation in a more precise way.

When a qualified majority requirement correlates with a mandatory a priori constitutional review, the constitutional court has a special role. In these circumstances, the constitutional court is involved more frequently in current political debates, since the body has to reflect on the constitutionality of each qualified act. So the constitutional court can behave as a negative legislator: not only is the support of parliament, but also the consent of the constitutional court, necessary to enact a qualified act. While the parliament votes on the basis of the text itself, the constitutional court has to assess whether there are any constitutional concerns in the adopted act. $^{51}$ Therefore, owing to the mandatory a priori constitutional review, the constitutional court plays a quasi legislative role, which has already been highlighted in the previous section. The legislative role of the constitutional court is not only optional: the court constitutes a permanent element of the qualified legislative process. On the one hand, this quasi legislative position gives a special weight to the constitutional court; on the other hand, it undermines the independence of the body by involving it in the legislative process, which is closely influenced by day to day political debates.

Another important consideration is whether the constitutional court has the right to review constitutional amendments in a substantial way. ${ }^{52}$ It has been already mentioned that the substantial review of constitutional amendments requires a separate category of legal norms beyond the constitution, or there may be a hierarchy within the constitution itself, and each constitutional provision must be in harmony with certain fundamental principles. ${ }^{53}$ If we accept these preconditions, the constitutional review of qualified laws will have a secondary importance, following behind the assessment of constitutional amendments.

If qualified laws are seen as the extension of the constitution, the amendment of qualified laws constitutes a quasi constitutional amendment. Without a substantial review of constitutional amendments, the constitutional court can interact with the constitutional issues involved through a review of qualified laws. The room for manoeuvre of the constitutional court is

\footnotetext{
${ }^{49}$ Barna (2013).

${ }^{50}$ Bodnár (2012) 33-34.

${ }^{51}$ Szalbot (2012).

${ }^{52}$ Barak (2011) 321-41.

${ }^{53}$ Küpper (2004) 273.
} 
obviously reduced to the less important constitutional rules, since the fundamental principles are provided by the main text of the constitution itself. If constitutional amendments are reviewed by the constitutional court, there are two levels of legal sources above qualified laws within the hierarchy of norms. In these cases, the most important issues emanate from the substantial review of constitutional amendments; qualified laws must comply with the constitutional design, which might also be influenced by the constitutional court. Rulings based on the constitutional review of a qualified law should not contradict the decisions made during the assessment of constitutional amendments. In conclusion, qualified legislation only has a secondary role in the relationship between the government and the constitutional court. ${ }^{54}$

Legislation with a qualified majority undoubtedly increases the weight of the constitutional court as a constitutional actor. Below, we will identify other elements in this phenomenon. The constitutional court may review qualified laws on formal grounds: if the qualified majority requirement has not been met, the qualified act is constitutionally invalid. ${ }^{55}$ Apart from the formal review, qualified laws may also be assessed substantially: the constitutional court examines whether the qualified legislation remains within the limits of constitutional authorisation. This is often a very complex issue, which has both formal and substantial aspects. The formal issue is whether the law-maker has properly considered the constitutionally provided framework of qualified legislation. As regards the substantial element, the constitutional court focuses on whether the legislation has used the wide consent requirement within its constitutional scope. This could be decided by collating the act which is under constitutional review with those provisions of the constitution which constitute the sources of the qualified majority requirement. $^{56}$

Sometimes there are qualified and ordinary provisions within the same act, and it is the task of the constitutional court to provide an orientation to distinguish these two categories of statutory provisions. ${ }^{57,58}$ Finally, there might be a purely substantial review of qualified laws: these norms should be also in substantial compliance with the constitutional requirements, as should ordinary laws. Besides this, the role of the constitutional court is highlighted when a mandatory a priori constitutional review has been introduced into the constitutional system in question. Moreover, the weight of the constitutional court is further strengthened when it is entitled to review the substance of the constitutional amendments. ${ }^{59}$

The political character of the constitutional court is also a frequently debated issue. During the fulfilment of its task to defend the constitution, the constitutional court necessarily comes into conflict with certain political interest groups, and this always causes continuous political pressure on the court. ${ }^{60}$ This is inevitable if we take into account the strong link between the activities of the constitutional court and the legislative process. For these reasons, I do not

\footnotetext{
${ }^{54}$ Holló (1991) 744-46.

${ }^{55} 1 / 2017$. (I. 17.) Ruling of the Constitutional Court of Hungary, ABH 2017, 3.

${ }^{56}$ Németh (2013).

${ }^{57} \mathrm{~N}^{\circ} 86-217, \mathrm{DC}$ du 18 September 1986; 4/1993. (II. 12.) ruling of the Constitutional Court of Hungary, ABH 1993, 48.;

1/1999. (II. 24.) ruling of the Constitutional Court of Hungary, ABH 1999, 25.

${ }^{58}$ Camby (1998) 1695.

${ }^{59}$ Küpper (2004).

${ }^{60}$ Alberts (2012) 71-72.
} 
consider political activity around the constitutional court to be a disadvantageous tendency in itself. $^{61}$ Constitutional judges are elected as the outcome of a political process, so despite its inherently professional character, the constitutional court is not completely independent from political influence. ${ }^{62}$ This is also underpinned by the consideration that the constitutional judges must take into account the political and social context within which the ruling has been issued. I prefer to use the term 'autonomy' to describe the status of the constitutional court, which excludes any direct external orders or influence on the court. So the link between the constitutional court and the political sphere should not be considered an undesirable phenomenon, but rather a necessary element of modern constitutionalism. However, what should be prevented are situations in which political groups take on the role of the constitutional court, or wish to overturn some of its rulings. The presence of qualified laws makes these situations more likely, since the constitutional court plays a major role as a counterbalance to governmental power. This consideration is more important when a qualified law is attached to a mandatory a priori constitutional review. Theoretically, a mandatory a priori constitutional review reinforces the position of the constitutional court; however, in reality the accuracy of this statement depends on the practice and the attitude of the constitutional court itself, and on the procedural rules it follows. So it cannot be excluded that qualified legislation will strengthen the link between the constitutional court and the political arena. However, if this link becomes too strong, or becomes dominated by political actors, the proper functioning of the constitutional court could be undermined.

In what follows, it is necessary to make a clear distinction again between the formal and substantial review of qualified laws. The formal aspect provides an instrument for the constitutional court to endorse the requirement of a qualified majority in practice. If the constitutional court cannot review the endorsement of a qualified majority requirement for certain provisions, this concept becomes merely a theoretical rule, which can be easily overturned by the government.

Since the demand for qualified law provides a substantial role for a wide parliamentary consent during the legislative process, it is surrounded by proper safeguards. This is the reason why the constitutional court should review the endorsement of the wide consent requirement, and why it also has the competence to check whether the increased majority requirement is applied within what is covered by the constitution. In this case, an important distinction is whether the constitution stipulates a two-thirds majority for the fundamental or the detailed provisions of a particular field of legislation. ${ }^{63}$ Regarding the fundamental and detailed rules, the answer can never be absolute: it is up to the constitutional court to provide an appropriate orientation. The test envisaged for the scope of qualified legislation gives a more precise definition regarding what we should understand by the fundamental provision of a particular legislative field.

The substantive aspect is relevant, firstly for the distinction between the qualified and ordinary provisions. The review does not consider compliance with the whole constitution, but only decides whether a qualified majority is required for the particular provision at issue. The

\footnotetext{
${ }^{61}$ Holló (1991) 119-30.

${ }^{62}$ Holló (2004) 577-608.

${ }^{63}$ Art. I) (4) and Art. 40. of the Fundamental Law of Hungary [25.04.2011].
} 
review becomes more complex when the general substantial constitutionality of the qualified act is concerned. Each rule must be taken into account which affects the qualified act concerned, within the hierarchy of norms. In most cases this is equivalent to the constitution, but in some cases, the situation is more complex. One such case concerns the internal hierarchy within the constitution: there might be several levels of norms which affect the qualified acts. According to the other potential approach, qualified acts do not constitute a homogeneous category; there may also be a hierarchy amongst qualified laws themselves. For instance, in Hungary there were two forms of two-thirds majority before 2011: the two-thirds legislative majority of all deputies, and the same proportion of those parliamentarians who are present. ${ }^{64}$ In France, the Constitutional Council vested the organic law on the state budget with quasi constitutional force, and that act prevails over other organic laws. Both in France and Hungary, a separate category has been established for qualified laws on limitations of state sovereignty. ${ }^{65}$ In Spain, the organic statutes of autonomous communities are treated differently from other organic laws. ${ }^{66}$ In cases of substantial review, these special categories of legal sources should also be taken into account.

\section{QUALIFIED LAWS AS INSTRUMENTS TO LIMIT THE ROOM FOR MANOEUVRE OF FUTURE GOVERNMENTS}

Qualified laws affect not only the horizontal, but also the temporal aspect of the separation of powers. ${ }^{67}$ I have already briefly analysed those circumstances in which the government has a two-thirds majority in parliament and even qualified laws can be modified without the votes of the opposition parties. One can argue that the separation of powers is not only a static concept, but also has a temporal dimension. If the current government amends a qualified act, and future governments have no real chance to reconsider it, the room for manoeuvre of any future government or parliament may be significantly reduced. ${ }^{68}$ Therefore, qualified laws generate uncertainty, also in the long term, and considerably distort the logic of parliamentarism, which, in turn, weakens the controllability of the country. ${ }^{69}$ The temporal dimension of the separation of powers demonstrates in an appropriate way that qualified laws can be harmful for every political party, especially with regard to a constantly changing political situation.

The risk of qualified laws under a two-thirds parliamentary majority is the preservation of certain political preferences for the long term, and that these policies could only be overruled later by illegal means. As a consequence, the stability of the legal system is only illusory, and sharp conflicts are hidden behind the apparently constant legal environment. Those political groups who are left out of the legislative process will always use more radical methods to realise

\footnotetext{
${ }^{64}$ Papp (1999) 117-24.

${ }^{65}$ Art. E) (4) of the Fundamental Law of Hungary [25.04.2011]; 1260/B/1997. Ruling of the Constitutional Court of Hungary, ABH 1998, 816.; Art. 88. (3) of the Constitution of France (4.10.1958.); Art. 104. (1) of the Constitution of Spain (04.01.1978.).

${ }^{66}$ Chofre (1994) 215-24.

${ }^{67}$ Erdős (2011) 54-62.

${ }^{68}$ Möllers (2013) 80.

${ }^{69}$ Art. 40. of the Fundamental Law of Hungary.
} 
their goals, and to dismiss the government. ${ }^{70}$ According to the logic of parliamentarism, the government has a limited, but extensive authorisation during its mandate to implement its policies, but these competences should not overstep the term of office of the government in question. The unilateral amendment of qualified laws may be interpreted as an ultra vires act by the pro-governmental parliamentary majority. ${ }^{71}$ From the perspective of the government, such steps are necessary due to the opposition's unwillingness to participate in the law-making process. The issue of a two-thirds parliamentary majority is extremely relevant in Hungary, but not in other countries which operate with a qualified majority, because most of these legal systems use the absolute majority requirement instead of the two-thirds majority. With the absolute majority, the exact proportion of the parliamentary majority is irrelevant; the only requirement is the stable majoritarian support behind the government. The government can amend qualified acts without a two-thirds parliamentary majority, and future governments will have the same room for manoeuvre. So an absolute majority is less dangerous from the perspective of the separation of powers, since the current government cannot interfere in the competences of its successors. The situation is slightly different when the amendment of the constitution is subject to a two-thirds majority of all deputies, while qualified laws can be modified with a two-thirds majority of all the parliamentarians who are present. There is no real chance to reconsider even the constitution or qualified laws, which can virtually exclude the opposition from the political discourse. The stability of the constitutional system is an important value, but it entails considerable risk factors if no effective legal mechanism is provided for the amendment of the existing framework.

The weight of the temporal dimension of the separation of powers also depends on which particular fields of legislation are covered by the qualified majority requirement. The main organs of the state, and fundamental rights have primary importance; therefore, the wide consent requirement for these statutes relies on the need for social support which lies behind the constitutional framework. It is more difficult when certain public policy matters are also subject to the heightened level of legislative majority. The Fundamental Law of Hungary stipulates that cardinal laws should regulate the acquisition of agricultural land and the fundamental rules of the pension- and the tax system. ${ }^{72}$ Such an application of qualified law is also known in other countries, such as Romania. ${ }^{73}$ If, besides the main organs of the state and fundamental rights, public policy matters also fall within the scope of qualified law, the room for manoeuvre of the current government is significantly diminished. In modern constitutional systems, fundamental rules should be distinguished from those which reflect current political demands. For the first category, the necessity of a qualified majority is relatively well-founded; however, the arguments are not so convincing for the second subgroup. The tax system, pensions, education and healthcare are sectors which are always at the core of political debate during an electoral campaigns. ${ }^{74}$ In these fields, there should be provisions with fundamental principles, where a qualified majority might be reasonable. Here, one may argue that the definition of a qualified act

\footnotetext{
${ }^{70}$ Szentgáli-Tóth (2015).

${ }^{71}$ Pozsár-Szentmiklóssy (2017) 281-90.

${ }^{72}$ Art. P) (2) and 40. of the Fundamental Law of Hungary [25.04.2011].

${ }^{73}$ Art. 44. (2) of the Constitution of Romania [21.12.1991].

${ }^{74}$ Dezső (1995) 84-91.
} 
is not based on a coherent logic. ${ }^{75}$ The classification as a qualified law is not always grounded on an objective system of criteria, and it is also questionable whether such an objective scale would be imaginable. However, it is at least certainly advisable to leave public policy matters within the room for manoeuvre of the current government; otherwise, the most important legal codes cannot be amended over the long term, and so become distant from social realities. ${ }^{76}$

It is also worth considering that although there are minor differences among various countries, qualified laws concern each branch of power and each constitutional actor. Qualified laws cover the competences and functioning of the parliament, the judiciary, the constitutional court, the ombudsman, the audit office, and the details of law-making. Apart from influencing the relationship between the constitutional actors, qualified laws also determine the detailed legal framework of the separation of powers. The system of the separation of powers is outlined by the constitution, but several important details are provided by qualified laws. Qualified laws can also be perceived in the vertical aspect of the separation of powers: if there are autonomous communities in the given country, their status is designated by qualified acts. This tendency is demonstrated well in Spain and in some Latin-American countries, where organic laws cover the relationship between the central government and autonomous communities. ${ }^{77}$

\section{QUALIFIED LAWS AND THE SEPARATION OF POWERS IN DIFFERENT CONSTITUTIONAL SYSTEMS}

In the following, the three most important constitutional systems with qualified law, i.e. France, Spain and Hungary, will be analysed and compared briefly, to consider what kind of impact qualified laws have had on the separation of powers.

In France, one of the key considerations behind the introduction of organic laws was to restructure the separation of powers. ${ }^{78}$ De Gaulle and his colleagues argued that the parliament was vested with too broad competences, which undermines stable governance, since the parliamentary majority behind the government is always uncertain. During the Fourth Republic, France was apparently governed by the parliamentary majority instead of the government itself. De Gaulle held the overly strong position of Parliament responsible for the instability of the Fourth Republic; therefore, his reforms aimed to weaken the parliamentary powers. ${ }^{79} \mathrm{He}$ considered organic laws an important instrument to achieve this goal, with a heightened required parliamentary majority, and with the implementation of a mandatory a priori constitutional review of organic laws. ${ }^{80}$ So the French organic laws highlight the role of the Constitutional Council, ${ }^{81}$ but it should also be noted that since 2008 an a posteriori constitutional review has also been in existence. ${ }^{82}$ However, an a

\footnotetext{
${ }^{75}$ Johnson (2006).

${ }^{76} 43 / 2012$. (XII. 20.) ruling of the Constitutional Court of Hungary, ABH 2012, 296.

${ }^{77}$ Art. 81. (1) of the Constitution of Spain (4.1.1978).

${ }^{78}$ Blacher (2012) 11-23.

${ }^{79}$ For more details, see: Giles (1991).

${ }^{80}$ Verpeaux (2007) 101.

${ }^{81}$ Camby (1989) 1401.

${ }^{82}$ Ducoulombier (2010) 688-708.
} 
posteriori constitutional review cannot be initiated on the ground of an unlawful neglect of the organic legislative process; ${ }^{83}$ only cases involving the substantive unconstitutionality of organic laws can be heard by the Constitutional Council. ${ }^{84}$ Organic laws cover the status of the president of the republic, the election and functioning of the legislation, and the framework of the judiciary, ${ }^{85}$ so their role is decisive for each branch of power. ${ }^{86}$ While the two-thirds majority model of qualified law aims to limit the power of the government, the French approach based on an absolute majority focuses on the legislative process. This is clearly demonstrated not only by the introduction of a mandatory a priori constitutional review in France, but also by the possibility in Hungary to link a bill of a qualified law to a vote of no confidence, which is not allowed in France. $^{87}$

In Spain, qualified laws influence the vertical aspect of the separation of powers. The organic laws on the status of autonomous communities are treated differently from other organic laws; these special acts regulate the relationship between the central government and the autonomous communities. Since there are several autonomous region in Spain with significant territory and economic weight, this function of organic law should not be underestimated. Apart from this, the Spanish organic laws also regulate the framework of the legislation and the judiciary, and a separate and special organic law outlines the status and functioning of the constitutional court. In Spain, the absolute majority model of qualified law is applied, but a mandatory a priori constitutional review has been also introduced for the status of autonomous communities. Spanish organic laws primarily influence the separation of powers via direct regulation; the other aspects are not experienced frequently due to the lower majority required.

In Hungary, the different models of qualified law should be taken into account. The laws with constitutional force concentrated on the protection of political minorities, and the primary aim was to require wide consent during the decision-making process. This approach limited the logic of parliamentarism considerably; therefore, it was not sustainable in the long term. The new version of qualified law, which was referred to as 'laws adopted with a two-thirds majority', also protected the parliamentary opposition, although within a rational structure. The opposition was awarded the right to participate effectively in certain decision-making processes, but this role was strictly restricted. ${ }^{88}$ This relative balance remained until 1994, when the left-wing coalition obtained a two-thirds majority in parliament. Although the fact that this strong coalition refused to adopt a new constitution without the participation of the opposition, several qualified acts were amended by the two-thirds governmental parliamentary majority. ${ }^{89}$ During the two decades after 1990, we experienced in practice the arguments about the relationship between two-thirds majority legislation and the separation of powers, with all of their advantages and disadvantages.

\footnotetext{
${ }^{83}$ Guillaume (2010).

${ }^{84}$ Décision en 2012. 278 QPC du 5 Octobre 2012; CC, 25 mars 2014, 2014-386 QPC.

${ }^{85}$ Sirat (1960) 153-60.

${ }^{86}$ Rogoff (2011) 257-66.

${ }^{87}$ Avril and Gicquel (2014) 267-307.

${ }^{88}$ Smuk (2007) 62-73.

${ }^{89}$ Kukorelli (2006).
} 
Since 2010, following the new composition of the Parliament and the adoption of the

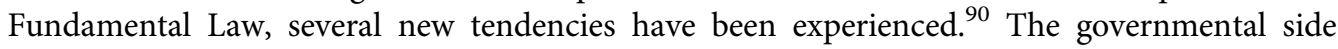
again had the opportunity to amend the constitution and qualified laws unilaterally. The Fundamental Law reconsidered the scope of qualified law, which also affected the relationship between qualified laws and the separation of powers. Fundamental rights are not covered by qualified laws under the Fundamental Law; therefore, it is more important than earlier that the instruments for the protection of these rights, such as the constitutional court and the ombudsman, are subject to the qualified majority requirement. Instead of fundamental rights, certain public policy matters fall within the scope of qualified laws; therefore, the Fundamental Law restricts more severely the room for manoeuvre of the current government than the previous constitution did. ${ }^{91}$

\section{CONCLUSION}

The presence of qualified law always influences the concrete framework and the emphases present in the separation of powers, and this impact may be focused either on the status of the government, or the parliament. In the absolute majority model, the role of the parliament is reduced, while a two-thirds majority limits the room for manoeuvre of the government. Qualified law is not only relevant in the relationship between the government and the parliament, but also has a serious impact on the constitutional status of the constitutional court. The outcome of this assessment is the conclusion that the implementation of qualified law does not serve effectively the establishment of the rational model of checks and balances, and serves as a tool for populist political regimes to safeguard their power. Some actors have an overly strong position of power, while others are excluded from the political process in the long term. To summarise, one may argue that a too broad application of qualified law distorts the logic of parliamentarism; its disadvantages are even stronger than its advantages. Qualified laws are expedient only for the statutory regulation of certain key constitutional organs of the state.

\section{REFERENCES}

Alberts, S., Warshaw, C. and Weingast B. R., 'Democratization and Countermajoritarian Institutions: Power and Constitutional Design in Self-Enforcing Democracy' in Ginsburg, T., (ed), Comparative Constitutional Design (Cambridge UP 2012) 71-72.

Avril, P. and Gicquel, J., Droit parlamentaire (Dalloz 2014).

Barak, A., 'Unconstitutional constitutional amendments' (2011) 44 Israel Law Review 321-41.

Barna, D. and Szentgáli-Tóth, B., 'Stabilitás vagy Parlamentarizmus? - A sarkalatos törvényekkel kapcsolatos egyes jogalkotási problémák' (Stability or parliamentarism? Certain legislative issues concerning cardinal laws) (2013) Ars boni <www.arsboni.hu/barnaszentg.html> accessed 30 July 2020.

Bibó, I., Válogatott tanulmányok. II. (Selected studies) (Magvető 1986).

${ }^{90}$ Johnson (2006).

${ }^{91}$ Szentgáli-Tóth (2014). 
Blacher, P., Le Parlement en France (LGDJ 2012).

Bodnár, E. and Módos, M., 'A jogalkotás normatív kereteinek változásai az új jogalkotási törvény elfogadása óta' (The change of the normative environment of legislation from the adoption of the new act on legislation) (2012) <www.academia.edu/9640621/A_jogalkot\%C3\%A1s_normat\%C3\%ADv_ kereteinek_v\%C3\%A1ltoz\%C3\%A1sai_az_\%C3\%BAj_jogalkot\%C3\%A1si_t\%C3\%B6rv\%C3\%A9ny_ elfogad\%C3\%A1sa_\%C3\%B3ta> accessed 15 Aug 2020.

Camby, J-P., La loi organique dans la Constitution de 1958 (RDP 1989).

Camby, J-P., 'Quarante ans de lois organiques' (1998) Revue de droit publique 5-6 1686-98.

Chofre, S. J. F., Significado y función de las leyes orgánicas (Tecnos 1994).

Conversi, D., 'The Smooth Transition' (2002) 4 National Identities 223-244.

Cservák, Cs., 'A hatalommegosztás elmélete és gyakorlati megvalósítása' (The theory and practice of separation of powers) (2002) 1 Jogelméleti Szemle <jesz.ajk.elte.hu/cservak9.html> accessed 11 July 2020.

David, R., Les grands systemes de droit contemporains (Dalloz 1964).

Dezső, M., 'A választási rendszer életképessége és anomáliái' (The viability of the electoral system and its anomalies) in Bőhm, A. and Szoboszlai, Gy. (eds), Parlamenti választások, 1994. Politikai Szociológiai Körkép (MTA Politikai Tudományok Intézete 1995) 84-91.

Ducoulombier, P., 'Rebalancing the power between the Executive and Parliament: the experience of French constitutional reform' (2010) 4 Public Law 688-708.

Erdős, Cs., 'Az alkotmány stabilitásának aktuális kérdései' (The current issues of stable constitutionalism) (2011) 1 Diskurzus 54-62.

Federalist Papers No. 51. (Required Foundation Documents 1788)<https://www.phoenix.k12.or.us/cms/lib/ OR50000021/Centricity/Domain/1172/APGovRFD\%201788\%20Federalist\%2051.pdf > accessed 13 July 2020.

Giles, F., The Locust Years: The Story of the Fourth French Republic, 1946-1958 (Secker \& Warburg 1991).

Guillaume, M., 'La question prioritaire de constitutionnalité' (2010) Justice et cassation, revue annuelle des avocats au Conseil d'État et à la Cour de cassation <www.conseil-constitutionnel.fr/conseilconstitutionnel/root/bank_mm/QPC/qpc_mguillaume_19fev2010.pdf> accessed 18 July 2020.

Hajdú, L., 'A rendi monarchia' (The feudal monarchy) (Rubicon 1997) <www.rubicon.hu/magyar/oldalak/ a_rendi_monarchia/> accessed 11 July 2020.

Holló, A., 'A hatalommegosztás, mint alkalmazott alapelv az alkotmánybíráskodás kialakulásának tükrében' ['Separation of powers as a fundamental principle during the initial stage of the Hungarian constitutional adjudication'] in Tóth, K. (ed), Kovács István Emlékkönyv (JATE ÁJK 1991) 119-30.

Holló, A., 'Alkotmánybíráskodásunk a közjog és a politika metszéspontjában' ['Our constitutional adjudication on the edge of law and politics'] (1991) 46 Élet és Tudomány 744-746.

Holló, A., 'Az Alkotmánybíróság tizenöt éve' (Fifteen years of the Constitutional Court of Hungary) (2004) 54 Magyar Közigazgatás 577-608.

Jakab A. and Szilágyi E., 'Sarkalatos törvények a magyar jogrendszerben' (Cardinal laws in the Hungarian legal system) (2014) Új Magyar Közigazgatás 3 96-110.

Johnson, N., A Super Bad Idea: Requiring a Two-thirds Legislative Supermajority to Raise Taxes Protects Special Interest Tax Breaks and Gives Budget Veto Power to a Small Minority of Legislators (Center on Budget and Policy Priorities 2006) <www.cbpp.org/research/a-super-bad-idea-requiring-a-two-thirdslegislative-supermajority-to-raise-taxes-protects> accessed 15 July 2020.

Kilényi, G., 'A parlament és a kormány viszonya a hatalommegosztás rendszerében' (The relationship of the government and the parliament within the framework of separation of powers) (1994a) 5 Magyar Közigazgatás 268-78. 
Kilényi, G., 'Az alkotmányozási folyamat és a kétharmados törvények' ['The constitution-making process and the qualified laws'] (1994b) 5 Jogtudományi Szemle 201-9.

Kukorelli, I., Az alkotmányozás évtizede. Közjogi, politikai tanulmányok, parlamenti jegyzetek (A decade of constitution. Public law, political studies, parliamentary notes) (Korona 1995).

Kukorelli, I., Tradíció és modernizáció a magyar alkotmányjogban (Modernisation and tradition in Hungarian constitutional law) (Századvég 2006).

Küpper, H., 'Az alkotmánymódosítás alkotmánybírósági kontrollja Magyarországon és Németországban' (The constitutional review of constitutional amendments in Germany and Hungary) (2004) 9 Jogtudományi Közlöny 265-74.

Küpper, H., 'A kétharmados/sarkalatos törvények jelensége a magyar jogrendszerben' (Cardinal laws in the Hungarian legal system) (2014) 46 MTA Law Working Papers 2-5.

Küpper, H. and Térey, V., 'A Kormány és tagjai országgyülési felelőssége' (The responsibility of the government and its members before the parliament) in Jakab, A. (ed), Az Alkotmány kommentárja (Századvég 2009) 1376-87.

Laski, H., Authority in Modern State (Yale UP 1919).

Leyland, P., The Constitution of the United Kingdom: A Contextual Analysis (Hart Publishing 2012).

Molnár, M., A Concise History of Hungary (Cambridge UP 2001).

Montesquieu, C. S., The Persian Letters (Translated by Healy, G., R., Bobbs-Merrill 1964).

Möllers, C., The Three Branches: A Comparative Model of Separation of Powers (Oxford UP 2013).

Montesquieu, C. S., Spirit of the Laws (Hafner Pub. Co. 1949).

Németh, M., 'Sarkalatos dilemmák' (Cardinal issues) (Ars boni 2013) <mandiner.hu/cikk/20130614_ nemeth_marton_sarkalatos_dilemmak> accessed 05 Aug 2020.

Papp, I., 'Kétharmaddal vagy a nélkül?' (With or without a two-thirds majority?) (1999) 3 Fundamentum $117-24$.

Petrétei, J., 'A parlamenti kontroll sajátosságairól' (On the special features of parliamentary control) in Bragyova, A. (ed), Ünnepi tanulmányok Holló András 60. születésnapjára (Bíbor 2003) 329-58.

Plato, The Republic (The Cambridge companion to Plato's Republic (ed), G. R. F. Ferrari, State University of New York Press 1996).

Pozsár-Szentmiklóssy, Z., 'Supermajority in Parliamentary Systems - A Concept of Substantive Legislative Supermajority: Lessons from Hungary' (2017) 3 Hungarian Journal of Legal Studies 281-90.

Rogoff, M. A., French Constitutional Law: Cases and Materials (Carolina Academic Press 2011).

Sári, J., A hatalommegosztás (The separation of powers) (Osiris 2000).

Sirat, C., La loi organique et la constitution de 1958 (Dalloz 1960).

Smuk, P., 'Ellenzéki jogok a parlamentben, különös tekintettel a parlament ellenőrzési tevékenységére' (Oppositional rights in the parliament with special regard to the control functions of the parliament) (2007) 2 Jogtudományi Közlöny 62-73.

Szalbot, B., 'Az Alkotmánybíróság hatásköreinek módosulása az új Abtv. tekintetében' (The competences of the Constitutional Court under the new act on the Constitutional Court) (Ars boni 2012) <arsboni.hu/ dolgozatok/alkotmanyjog/Szalbot_Balazs_Az_Alkotmanybirosag_hataskoreinek_modosulasa.pdf> accessed 15 Aug 2020.

Szentgáli-Tóth, B., 'Alkotmányos-e a minősített többség?' (Is qualified majority constitutional?) (Ars boni 2014) <jogaszvilag.hu/rovatok/szakma/alkotmanyos-e-a-minositett-tobbseg> accessed 7 July 2020.

Szentgáli-Tóth, B., 'Some Points Against Legislating with Two-Thirds Majority' (Lawyr it 2015) <www. lawyr.it/index.php/articles/reflections/543-some-points-against-legislating-with-two-thirds-majority> accessed 7 July 2020. 
Troper, M., 'The Development of the Notion of Separation of Powers' (1992) 26 Israel Law Review 1-15. Troper, M. and Chagnollaud, D. (eds), Traite international de droit constitutionnel (Dalloz 2012). Verpeaux, M. and Maryvonne, B., Le Conseil constitutionnel (La documentation française 2007).

Open Access. This is an open-access article distributed under the terms of the Creative Commons Attribution 4.0 International License (https://creativecommons.org/licenses/by/4.0/), which permits unrestricted use, distribution, and reproduction in any medium, provided the original author and source are credited, a link to the CC License is provided, and changes - if any - are indicated. (SID_1) 